\title{
DESIGN, FABRICATION AND PERFORMANCE EVALUATION OF MELON SHELLING MACHINE
}

\author{
Adedoyin R. A ${ }^{1}$, Olatunde O. $B^{2}$, Ponle E. $A^{3}$ \\ ${ }^{1}$ Department of Mechanical Engineering Osun State Polytechnic Iree, Osun State. Nigeria. \\ ${ }^{2}$ Department of Mechanical Engineering Osun State Polytechnic Iree, Osun State. Nigeria. \\ ${ }^{3}$ Department of Mechanical Engineering University of Ibadan, Oyo State. Nigeria. \\ olatundeolanrewaju07@yahoo.com
}

\begin{abstract}
The design, fabrication and testing of melon shelling machine were carried out. Considering the numerous nutritional and economical importance of the melon seed (Egusi) it is only binding to fashion drudgery free and less expensive means of processing the seed. An insight was carefully taken from previous attempts on this work by various scholars. The machine has a power rating of $1.5 \mathrm{hp}$, power transmitted was 1656.70 wattsand was constructed using basically mildsteel. Performance test was carried out and the machine has efficiency of $62.5 \%$ for shelled melon, $10 \%$ for unshelled melon, $10 \%$ for breakage and $17.5 \%$ for partially shelled melon.
\end{abstract}

Keywords: Design, fabrication, melon seed, shelled, unshelled.

\section{INTRODUCTION}

Many attempts have been made by some intellectuals in designing and constructing a Melon Sheller. Some designs failed while others performed below expectation. This design was carried out to solve the boredom involved in melon shelling operation which is one of the major factors militating against the scale production of this cropKolawole S.S (2012).It is as a result of this that we were prompted to improve the existing design of such a machine. It has been observed by Makanjuola that the traditional melon shelling method suggests that a device to bend the seed sufficiently until the shell breaks is required.

The primary aim of this work is to design a shelling machine having efficiency well above $60 \%$ and the objectives are to save shelling time, enhance the performance of shelling machine, reduce cost of shelling, and above all to increase the rate of production of well shelled melon seed. With these objectives in mind, two different materials (flat bar and flexible rubber) where used for the shelling bar in order to test shelling efficiency of both materials.

\section{METHODOLOGY}

Element of Shelling according to Sharma C.S \& Purhit K (2003), was done where mean of unshelled melon thickness is $1.71 \mathrm{~mm}$ and that of shelled melon is $1.60 \mathrm{~mm}$, hence clearance is $0.06 \mathrm{~mm}$. Weights of melon and chaff are given as; weight of unshelled melon is $0.000932 \mathrm{~N}$, weight of shelled melon is $0.000875 \mathrm{~N}$ while the weight of chaff is $0.0000147 \mathrm{~N}$.Factors considered in the choice of materials for the machine production include rigidity, critical speed, flexibility of components, type of stress to which, they may be subjected. The manufacturing processes were carried out in the mechanical engineering fabrication workshop of Osun State Polytechnic Iree, Nigeria.

\subsection{DESCRIPTION OF MACHINE}

The machine consists of a cylinder shaft inserted in a cylindrical pipe, on which theshelling blades(shelling flat bar/ flexible rubber) were welded/attached round the cylindrical pipe at an angle. The bent shelling blades creates the slight bending effect on the melon seed required for shelling action, Fig 1 . The pipe rotate via a shaft attached to it which is been driven by an electric motor via a belt. The shaft consists of helix (Forming a continuous curve around the central point or axis) which serves as a conveyor. This conveys the shelled melon to the discharge after been shelled by the flat bars welded on the pipe. Melon seed is feed into the machine through the hopper, the shelling action is by rotating the flat bar on the pipe against the cylindrical wall by rubbing action. The melon is shelled and falls through an opening under the cylinder and a fan is incorporated under to blow off the chaff away from the seeds melon. Electric motor of $1.5 \mathrm{kw}$ was used to power the melon shelling machine.

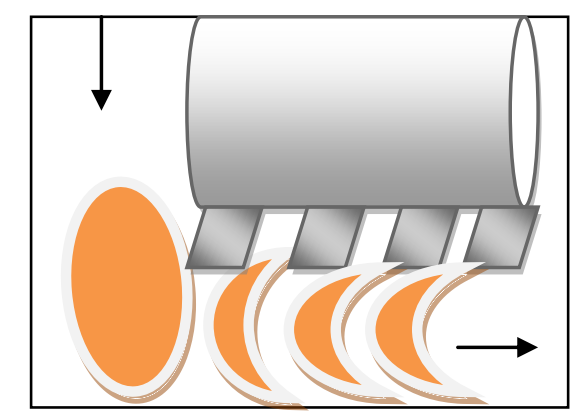

Fig.1. Slight Bending of the melon seed 


\subsection{DESIGN CALCULATIONS DESIGN THEORY}

The various components produced and tested were: Solid shaft, hopper, shelling cylinder, pipe and flat bars, bearing, frame and bearing house.

According to J.E Shirley (1989), Design for shelling pipe was given using the formula shown below

Shelling pipe area $A_{p}=\pi r^{2}$

$r_{p}=$ radius of the pipe; volume of shelling pipe

$\mathrm{V}_{\mathrm{p}}=\pi \mathrm{r}^{2} \mathrm{~L}_{\mathrm{P}}$

Where

$\mathrm{L}_{\mathrm{p}}=$ length of the shelling pipe

Area of shelling cylinder

$\mathrm{A}_{\mathrm{c}}=\pi \mathrm{r}^{2}$

Where

$\mathrm{r}_{\mathrm{c}}=$ radius of shelling cylinder; volume of shelling cylinder

$\mathrm{V}_{\mathrm{c}}=\pi \mathrm{r}_{\mathrm{c}}^{2} \mathrm{~L}_{\mathrm{c}}$

Clearance between shelling cylinder and shelling pipe

Where

$\mathrm{h}_{\mathrm{p}}=$ height of the flat bar on pipe.

$\mathrm{h}_{\mathrm{c}}=$ height of shelling cylinder

$\mathrm{V}_{1}=1 / 3 \mathrm{x}$ base area $\mathrm{x}$ height - volume for hopper

Where

$\mathrm{V}_{\mathrm{h}}=$ volume of hopper

$\mathrm{H}=$ height of hopper

\subsubsection{DESIGNS FOR SHAFT}

Design for shaft involves analyzing the various forces acting on the shaft and obtaining the required diameter that will withstand the force according to M.F Spotts (1991).were by shown below give us the Algebraic sum of forces acting on the member is equal to zero. That is

$\mathrm{R}_{\mathrm{A}}+\mathrm{R}_{\mathrm{B}}=\mathrm{W}_{1}+\mathrm{W}_{2}+\mathrm{W}_{3}$

$\mathrm{R}_{\mathrm{B}}=\mathrm{W}_{1}+\mathrm{W}_{2}+\mathrm{W}_{3}-\mathrm{R}_{\mathrm{A}}$

\subsubsection{SHEAR FORCES ON SHAFT (S.F)}

Shear force on shaft is the algebraic sum of forces acting to one side of the section according to Allen S.H and Alfred R.H (1982).the diagram shown below analyzed the Shear forces at various sections that is

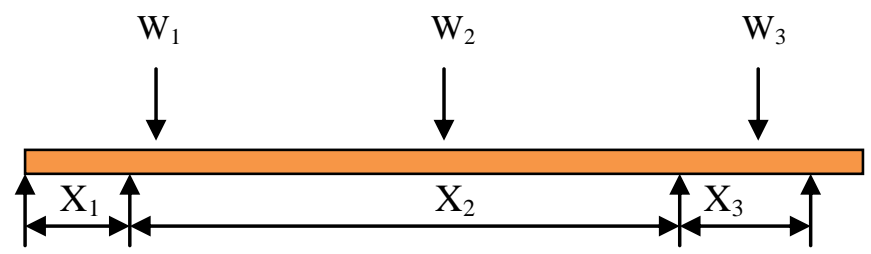

Fig.2. Forces Acting on Shaft

$=\mathrm{W}_{1}-\mathrm{R}_{\mathrm{A}}+\mathrm{W}_{2}-\mathrm{R}_{\mathrm{B}}+\mathrm{W}_{3} \quad\left(\mathrm{X}_{1}+\mathrm{X}_{2}\right) \leq \mathrm{X} \leq\left(\mathrm{X}_{1}+\mathrm{X}_{2}\right) \leq \mathrm{X} \leq$ $\left(\mathrm{X}_{1}+\mathrm{X}_{2}+\mathrm{X}_{3}\right)$

Forces required to rotate the shaft according to J.E Shirley (1989), $\dot{\omega}=$ Angular Velocity

$\mathrm{r}_{\mathrm{m}}=$ Radius of Motor Shaft

But

Where

$\mathrm{N}=$ Speed of Motor in rev/min

Torque is the work required in rotating the shaft.

Also $\mathrm{T}=\mathrm{Fr}_{\mathrm{s}}$

Where

$r_{s}$ is the shaft radius However, torque can also be obtained from the following relation:

Where

$\mathrm{T}=$ Applied Torque

$\mathrm{J}=$ Polar Moment of Area

$\imath=$ Shear Stress

$\mathrm{G}=$ Modulus of Rigidity

$\varphi=$ Angle of twist

$\mathrm{L}=$ Length of Shaft

\subsubsection{SPEED CONTROL}

The need to regulate or control the speed of the motor to some certain limit become necessary because too high speed will crush the melon and too low speed can over stress the shelling teeth. The formula crush the melon and too low speed can over stress the shelling teeth. The formula $\mathrm{N}_{1} \mathrm{D}_{1}=\mathrm{N}_{2} \mathrm{D}_{2}$ according to Sharma C.S and Purchit Kamalesh (2003), Where $\mathrm{N}_{1}=$ Speed of Electric Motor, $\mathrm{D}_{1}=$ Diameter of Pulley on Electric Motor, $\mathrm{N}_{2}=$ Speed of Shaft, $\mathrm{D}_{2}=$ Diameter of Pulley on Shaft.

\subsubsection{BELT DRIVE}

Belt drives uses the friction that exists between the pulley and belt to transmit a torque. The belt is stretched between the pulley with an initial tension $\mathrm{T}_{1}$, i.e. the one supply the torque to transmit the power via the friction between the contact surface of the belt and pulley. The transmitted torque is solely in the belt during operation, there being a "tight" side and a "slack" side

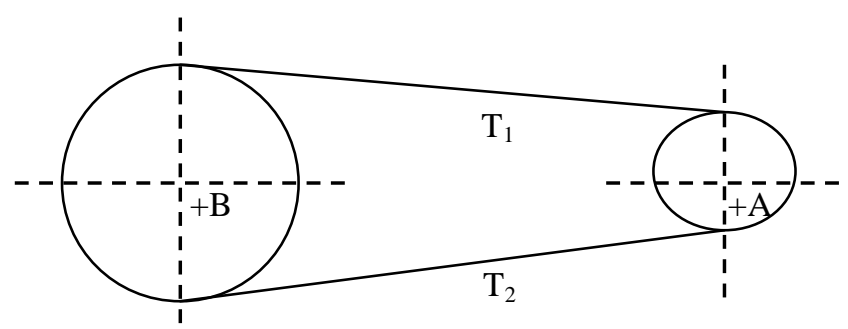

Fig.3. Vee-Belt

The belt selected in this design is the vee-belt. The vee belt Fig. 2, has a special tapered section of vee shape, which is located in vee grooves in the circumference of the pulley. This gives a positive location and increases the normal reaction between the contact surfaces of the belt and pulley. The belt tension ratio is given by

Where $\mathrm{P}=$ power of electric motor 
According to M.E Spotts (1988)

Where

$\theta$ is the angle of contact between the belt and the pulley, also known as the ship angle.

$\mu=$ Coefficient of Friction

$\alpha=$ The Pulley Grooves Angle

$\theta^{1}=$ Ship Angle in Radian.

\subsubsection{POWER TRANSMISSION BY BELT}

The driving pulley causes a difference in tension in the belt which is transferred to the driven pulley. The driven thus experiences a torque which is caused by the difference in tension in the belt. Since power transmission in belt involves two pulleys, then torque on driving pulley $\mathrm{A}$.

$=\left(\mathrm{T}_{1}-\mathrm{T}_{2}\right) \mathrm{r}_{\mathrm{A}}$

and torque on driven pulley $\mathrm{B}=\left(\mathrm{T}_{1}-\mathrm{T}_{2}\right) \mathrm{r}_{\mathrm{B}}$

Now, power transmitted $=$ Torque $\mathrm{x}$ Angular Velocity.

$\mathrm{P}_{\mathrm{A}}=\left(\mathrm{T}_{1}-\mathrm{T}_{2}\right) \mathrm{r}_{\mathrm{A}} \omega_{\mathrm{A}}$ from pulley $\mathrm{A}$

And from pulley $\mathrm{B}$

$\mathrm{P}_{\mathrm{B}}=\left(\mathrm{T}_{1}-\mathrm{T}_{2}\right) \mathrm{r}_{\mathrm{B}} \omega_{\mathrm{B}}$

But

and

which is equal to the speed and power transmitted
$=\left(\mathrm{T}_{1}-\mathrm{T}_{2}\right) \mathrm{r}$ Watts $\ldots$.

Where

$\mathrm{r}_{\mathrm{A}}=$ radius of Pulley on Electric Motor

$r_{B}=$ radius of the Pulley on Shaft (Shelling Shaft)

\subsubsection{LENGTH OF BELT}

according to Aaron D. Deustchamn (1975),

Where

$\mathrm{L}_{\mathrm{B}}=$ Length of Belt

$\mathrm{D}_{2}=$ Diameter of Pulley on Shaft

$\mathrm{D}_{1}=$ Diameter of Pulley on Electric Motor

$\mathrm{C}=$ Centre Distance Between Pulley.

\subsubsection{BEARING}

This is a machine part which supports another part which rotates slides or oscillates in it, or on it.Bearing are in different categories and types and their function is to reduce friction between two rotating parts. It reduces wear and reduces heat to be generated due to friction and support load on rotating parts.

For the purpose of this design a ball bearing of bore $25 \mathrm{~mm}$ was selected.

\subsection{DESIGN ANALYSIS}

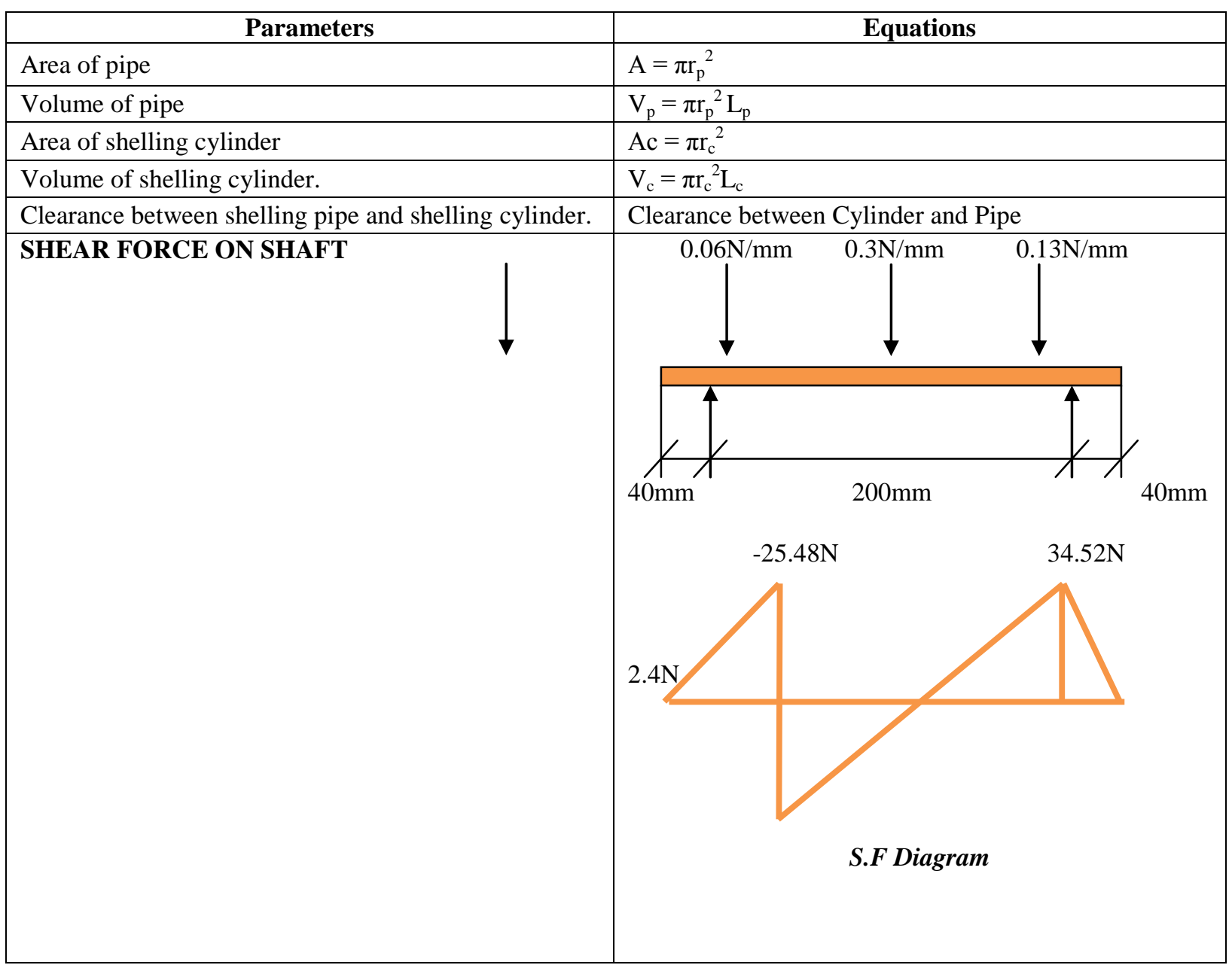




\begin{tabular}{|c|c|}
\hline Force required to rotate & \\
\hline $\begin{array}{l}\text { Speed reduction } \\
\text { From equation }\end{array}$ & $N_{1} D_{1} \pi=N_{2} D_{2} \pi$ \\
\hline BEARING SELECTION & $\begin{array}{l}\mathrm{P}_{\mathrm{r}}=\mathrm{XR}+\mathrm{YT} \\
\mathrm{P}_{\mathrm{r}}=\text { equivalent radial load } \\
\mathrm{L}_{10}=(\mathrm{C} / \mathrm{p}){ }^{\mathrm{k}} \times 10^{6} \\
\mathrm{C}=(2,420 \times 4.448) \mathrm{N} \text { from the bearing load table for } \\
\text { bearing having } 25 \mathrm{~mm} \\
\text { Bore } \\
\mathrm{K}=3 \text { for ball bearing } \\
\left.L_{10}=\frac{(2,420 \times 4.448}{818.4}\right)^{3} \\
=2275 \times 10^{6} \mathrm{rev}\end{array}$ \\
\hline Capacity requirement, & $\begin{array}{l}C r=p\left(\underline{\mathrm{L}}_{10} \underline{\mathrm{N}}\right)^{1 / 3} \\
C r=\text { capacity requirement } \\
\mathrm{Z}=\text { constant for ball bearing from bearing table } \\
\mathrm{Cr}=1723589.98\end{array}$ \\
\hline
\end{tabular}

\subsection{TESTING OF THE MACHINE}

The efficiency of the melon shelling machine was determined by testing theprocessed melon seeds, wettedto increase the moisture content and thereby reduce the brittleness of the seed in order to ease the problem of seed breakage, since percentage seed breakage is found to reduce with increased moisture content of melon seed, Shittu and Ndrika (2012).Equally weighed melon seeds were fed into the machine via the hopper to test for percentage efficiency in both cases (flexible rubber and then flat bar).

\section{RESULTS AND DISCUSSION}

Table 1 below shows percentage performance of the machine in terms of shelled, unshelled, damaged and partially shelled melon seeds when the Flexible rubber and the flat bar were used for shelling. It is observed from the tabulated result shown that a higher percentage of seed was shelled making use of the Flexible rubber, likewise a higher percentage of partially shelled seeds was obtained. However, the advantage of a higher shelled seed out-weight the disadvantage of possible higher partially shelled seeds when the Flexible rubber is used.

Table 1: Calculated Percentage Efficiency Considering Shelled, Unshelled, Damaged and Partially Shelled Melon Seeds

\begin{tabular}{|l|l|l|l|l|}
\hline Method & $\begin{array}{l}\text { Percentag } \\
\text { e seeds } \\
\text { shelled } \\
(\%)\end{array}$ & $\begin{array}{l}\text { Percentag seeds } \\
\text { e sushelled } \\
(\%)\end{array}$ & $\begin{array}{l}\text { Percentag seeds } \\
\text { damaged } \\
(\%)\end{array}$ & $\begin{array}{l}\text { Percentag } \\
\text { e seeds } \\
\text { partially } \\
\text { shelled } \\
(\%)\end{array}$ \\
\hline $\begin{array}{l}\text { Flexibl } \\
\text { e } \\
\text { rubber }\end{array}$ & 70.95 & 6.5 & 4.75 & 17.8 \\
\hline Flat bar & 62.5 & 10.0 & 10.0 & 17.5 \\
\hline
\end{tabular}

\section{CONCLUSION}

In this work, the melon shelling machine was designed, constructed and tested using two different materials (flat bar and flexible rubber) for shelling with $62.5 \%$ and $70.95 \%$ efficiency respectively. A need to bend the melon seed sufficiently till breakage, requires some amount of flexibility which is evident in the greater percentage seeds shelled, lesser percentage seed unshelled, and lesser percentage damaged seeds, obtained from using the flexible rubber. However, the use of flexible rubber lead to higher percentage seeds partially shelled, this disadvantage does not out weigh the above mentioned advantages observed by making use of the flexible rubber.This shows the improvement in performance of melon shelling machine as a result of the design flexibility.

\section{REFERENCES}

[1] Aaron D. Deustchamn (1975), Machine Design (theory and practices) CollierMacmillan Publishers.

[2] Adekunle A.S (2009),Development and Performance manually \& motorized melon shelling machine.

[3] Allen S.H and Alfred R.H (1982), Theory and Problems of Machine Design McGrew-Hill Book co. Singapore pp. 114, 138 and

[4] Kolawole S.S (2012),Development and Performance tests of a melon (Egusi) Seed

[5] Orisaleye J.T, Danisa O, Ojolo S.J \& Ogbonanya C. (2010). Design and Development of Cashew Nut Shelling Machine.

[6] Sharma C.S and Purchit Kamalesh (2003), Design of machine elements, Prentice Hill of Indian, New Delhi.

[7] Shirley J.E (1989), Mechanical Engineering Design. $5^{\text {th }}$ Edition, Mc Grew-Hill Book co. pp 54, 55 and 93.

[8] Shirley J.E (1989),Mechanical Engineering Design. $5^{\text {th }}$ Edition, Mc Grew-Hill Book co. pp 389 - 399. 
[9] Spotts M.E. (1988), Design of Machine Element, $6^{\text {th }}$ Edition, Prentice Hill of Indian Private Limited, New Delhi pp 149 - 157.

[10] Spotts M.E. (1991),Design of Machine Element, Prentice Hill of Indian Private Limited, $6^{\text {th }}$ Edition.

[11]S. K. Shittu and V. I. O. Ndrika., (2012). Development and performance tests of a melon (egusi) seed shelling machine. Agric Eng: CIGR Journal, issue 14, Pp. 1 